\title{
The Political Stakes of Academic Research: Perspectives on Johannesburg
}

Ivor Chipkin

\begin{abstract}
This article considers a burgeoning literature on Johannesburg from the perspective of the sorts of questions it asks about the city. There is a substantial and lively literature on questions of poverty and equality, class and race. These studies are strongly informed by the idea that the mechanisms that produce such inequalities are key to understanding the nature of Johannesburg as a city: in terms of how its economy works and how political institutions function, but also in terms of what sort of city Johannesburg is and can be. I consider sociological and economic studies of the inner city that try to account for demographic shifts in the inner city and for processes of social and physical degeneration. I review urban anthropologies of inner-city society, considering in particular new forms of social and economic organization among inner-city residents. Related to these, I discuss debates among scholars about the prospects for governing the city, paying special attention to the consequences for such readings on partnerships. I also discuss an emerging literature, critical of that above, which seeks to shift analysis of the city toward studies of culture and identity. These literatures do not simply approach the city through different disciplinary lenses (sociology or economy or anthropology or cultural studies). They come to their studies from different normative perspectives. For some, the key political question of the day is one about social and political equality in its various forms. For others, it is about the degree to which Johannesburg (or Africa) is different from or the same as other places in the world. This paper has tried to bring to the fore the political (and not simply policy) consequences of these different views. It concludes not by seeking to reconcile these perspectives, but by suggesting a way of retaining a commitment to equality and justice while not reducing them simply to questions of economy. At stake, I argue, are questions of democratic culture and of sociability.
\end{abstract}

African Studies Reviow, Volume 48, Number 2 (September 2005), pp. 87-109 Ivor Chipkin earned his doctorate degree at the Ecole Normale Superieure in Cachan. He worked at the University of the Witwatersrand and recently became an Oppenheimer senior associate member of St. Antony's College, University of Oxford. He was involved in the democratic transition of local government in South Africa, chairing in 1996 one of the key national commissions that prepared for the White Paper on local government. 
Résumé: Cet article considère la littérature bourgeonnante sur Johannesburg sous l'angle du questionnement qu'elle engendre à propos de la ville. Il existe une littérature vivante et importante sur les questions de pauvreté et d'égalité, de classe et de race. Ces études sont fortement influencées par l'idée que les mécanismes produisant ces inégalités sont des éléments clé pour comprendre l'essence de Johannesburg en tant que ville: comment son économie et ses institutions fonctionnent, mais aussi quelle sorte de ville Johannesburg est et peut devenir. Je prends en considération des études sociologiques et économiques de la ville qui tentent de décrire les évolutions démographiques, ainsi que les processus de dégénération sociale et physique. Je passe en revue des études anthropologiques de la société urbaine, tenant compte en particulier des nouvelles formes d'organisation sociale et économique entre résidents dans la zone urbaine. En corrélation, j'entre en discussion avec les débats des chercheurs concernant les principes de gouvernance de la ville, en portant une attention toute particulière aux conséquences de telles lectures sur les partenariats formés. Je prends également en considération une littérature émergente, critique de celle mentionnée ci dessus, qui cherche à délaisser les études de la ville pour se centrer sur des études culturelles et identitaires. Ces littératures posent non seulement un regard différent sur la ville à travers des disciplines différentes (sociologie et économie ou anthropologie, ou études culturelles), mais elles proviennent surtout de perspectives normatives différentes. Pour certains, la question politique à l'ordre du jour est l'égalité sociale et politique, dans ses différentes formes. Pour d'autres, ce qui importe c'est le degré de conformité ou de différence existant entre Johannesburg (ou l'Afrique) et les autres endroits du monde. Cet article tente de placer sur le devant de la scène les conséquences politiques (et pas seulement législatives) de ces différentes perspectives. Les conclusions apportées ne tentent pas de réconcilier ces approches mais de suggérer une manière de conserver un engagement pour l'égalité et la justice tout en ne les réduisant pas uniquement à des questions économiques. Les notions qui importent vraiment, selon moi, sont les questions de culture démocratique et de sociabilité.

\section{Introduction}

Over the last couple of years there have been a host of new publications about Johannesburg. Lindsay Bremner released Johannesburg: One City, Colliding Worlds (Johannesburg, 2004). Public Culture, the prestigious American journal, published "Johannesburg: The Elusive Metropolis," a special edition of essays compiled by Achille Mbembe and Sarah Nuttall (vol. 16, no. 2, 2004). Jo Beall, Owen Crankshaw, and Susan Parnell released Uniting a Divided City: Essays on Governance and Social Exclusion in Johannesburg (Lon- 
don, 2002). In 2003 Richard Tomlinson, Robert A. Beauregard, Lindsay Bremner, and Xolela Mangcu published an edited collection of essays on the postapartheid city. Clive Chipkin will shortly publish his second book on the architectural history of the city. In addition to these, Johannesburg has received attention in reports on migration and transnationalism, as well as coverage in the national press. Taken together, this literature suggests a current academic interest in Johannesburg not seen since the political-economic readings of the city in the late $1980 \mathrm{~s}$ and early 1990s.

In this paper I will offer a critical review of the recent academic writing on Johannesburg as it relates to the inner city. I intend to make explicit debates within this literature and their consequences not simply for policymaking, but more especially, for what I will discuss as the notion of the city. We will see, for example, that for some authors the city is primarily a political-economic system, where the central questions are ones of poverty and marginalization. For others the city is treated more from the perspective of municipal institutions, such that the challenges relate to management and to governance. For still others, the city is examined from the perspective of culture. Here the chief questions relate to the circulation of commodities and the flows of signs and symbols.

For the purposes of exposition, I will discuss this literature thematically, according to the following topics: the legacy of the apartheid city, governance and regulation, and cultures of the city. A thematic presentation should not obscure the very real conceptual differences among some of these essays. In other words, it is not simply that different authors treat different facets of the same problem, or the same topic. Academic articles are not like compendiums of images or maps that, when puzzled together, produce a complete picture. The effect of combining them, that is, is not necessarily a broader or more comprehensive view of the city. Sometimes what writers choose to study is related to the academic disciplines from which they hail. It is unsurprising that a sociologist will pose questions about social life, whereas an economist will be more interested in the functioning of markets, and so on. We should be careful, however, not simply to suppose that when sociologists and/or planners use the term "city" that they mean the same thing. They may not. We are familiar with the term "black," for example. During the $1970 \mathrm{~s}$ and $1980 \mathrm{~s}$, when writers in the tradition of Black Consciousness or négritude invoked the term, they emphasized more the cultural dimensions of blackness. In contrast, when political economists used the term, they intended a people oppressed and exploited by a system of racial capitalism. In both cases, the same term was used, yet it referred to quite different things. We need to be alert to such differences when it comes to discussions of the city. We will see, for example, that in some cases, authors writing on Johannesburg use the word "city" in a sense very different from the one intended by the Johannesburg Development Agency or the Metropolitan Council. This is not simply a matter of academic interest. It has important political consequences. At stake is the value 
attached to questions of poverty, inequality, identity, and culture.

I will end, not by seeking to reconcile these perspectives, but by suggesting a way of retaining a commitment to equality and justice while not reducing them simply to questions of economy. What matters are questions of democratic culture, and of sociability.

\section{Normative Perspectives}

Sometimes what academics find interesting or important is determined not simply by the academic fashion of the day, or by disciplinary concerns, but by an implicit normative relation to their object. In other words, they deem certain questions more important than others because they are interested in certain social or political values. For example, from the period between 1965 and the late 1980s, many academic enterprises where interested in questions of equality and freedom in their various forms (social, political, economic). Literatures about capitalism, about colonialism, about racism, irrespective of their discipline, sought to understand the way that economies, political regimes, concepts, and so on, reproduced or legitimized unequal relations between classes, between countries, between regions, between races, between genders. They did so usually because they believed that inequality was unjust. This instinct has long informed South African scholarship on the city.

In the introduction to Emerging Johannesburg (Tomlinson et al. 2003), to take but one example, the editors situate the collection of essays in the context of the dissolution of apartheid. With the extension of civil, political, and social rights to all South Africans, the city could no longer be conceived as a place of white belonging. Suddenly numerous and diverse claims were made on the city, with varied attendant images of the sort of city Johannesburg should be. A multiplicity of Johannesburgs came into being, they suggest (2003: ix). Yet the challenge for the city, like the country, is not simply to reconcile competing interests. What matters most is that in transforming Johannesburg, barriers are lifted to nonracial justice. In other words, certain visions of the city trump others. It is not enough simply to represent key interests or apportion resources among them, they suggest. Competing interests need to be accommodated in a way that helps realize the imperative of a just and nonracial Johannesburg. What does this entail, according to the editors? It means addressing poverty, high unemployment, lack of access to decent housing, and inequality in a host of other areas. Let us pause here. What is important to notice is the way that Tomlinson et al. frame the "problem of the city." At stake are questions of justice and nonracialism and belonging. Put differently, belonging to the city is framed as a question of equal access to services and to work. This is the normative horizon that informs their book, the ethical presuppositions that consciously or unwittingly make some questions good questions. These 
authors ask the questions they do because they believe that the conditions of social equality are key to understanding the city. In this way, Emerging Johannesburg falls in the wake of a long tradition of urban studies in South Africa.

At least since the end of the 1980s, academic writing on Johannesburg and other cities has been interested in the way the political and spatial configuration of the city produced an urban political economy that prejudiced blacks and the poor. We are familiar with these arguments, and they fall outside of the ambit of this study. If we nonetheless summarize their key arguments we can say the following: The notion of the apartheid city was not simply a shorthand to describe racial segregation as it manifested itself spatially. Rather, the term spoke to an urban political economy that reproduced wealthy white cities while simultaneously underdeveloping black areas. What these analyses privileged where questions of housing, urban poverty, social justice, and access to services. We should not be surprised, therefore, that academic interest in the postapartheid city continues in this tradition of inquiry. Even when there are (sometimes fierce) disagreements about what is to be done, all implicitly agree that the key questions about the city are those of segregation, poverty, and inequality. In short, such studies are concerned with the legacy of the apartheid city on the new metropolitan order.

Within this literature we can describe several tendencies. There are studies that monitor trends and patterns with regard to racial segregation, property markets and the urban form; discuss shifts in regimes of governance in the inner city, and the limits to metropolitan authority and plans (decentralization, integrated planning, regulation); and focus on political and ideological changes as they concern urban management.

More recently, a critique that has become preeminent elsewhere has arrived in South Africa. For the last twenty years or so, some writers have questioned the universal ambitions of such studies and wondered aloud about the Eurocentrism implicit in many of their concepts. The argument, somewhat telescoped, goes like this: The notions of freedom and justice implicit in these studies were based on Western, usually European, norms that represented themselves as universal. When such writings, they continue, imagined what a free person looked like, they saw a white, Christian, heterosexual, European man. Postcolonial and feminist studies sought to show how these notions of justice served to exclude women, Africans, Indians, and Asians in the name of universalism. How could an African woman ever be free if the measure of freedom was a white man? What emerged was an interest in questions of culture and the way that ethical and/or political values are culturally specific. Although the field of "cultural studies" as it has emerged since then has little resemblance to what earlier and founding scholars intended by the term, it has become closely associated with studies of popular culture, the body, and what is sometimes called "selfstyling." More shall be said about this later. For the moment let us merely 
note that what these studies find interesting are questions of cultural difference and/or cultural sameness. We will see how some of the emerging literature on Johannesburg resonates with these themes. We will see, too, how such work has important political consequences for how we understand the city.

By gathering the literature, not according to disciplines (geography, planning, politics, governance), but according to normative approaches, it will be easier to draw out commonalities among certain literatures-even when there are fierce disagreements between them-and profile differences with others.

\section{The Legacy of the Apartheid City}

The first major academic study of the inner city was conducted by Alan Morris and dealt specifically with Hillbrow. In Bleakness and Light (Johannesburg, 1999) Morris sought to understand how Hillbrow moved from being an exclusively white neighborhood in the 1960 s to being predominantly black by the mid-1990s. His intention was not to track urban politics or the influence of state policy on the inner city, but rather to analyze how desegregation affected what he called racial sentiments, interracial interaction, and friendship (4).

At a time when the government was seeking to co-opt coloureds and Indians to a political dispensation that gave them restricted political rights in a new constitutional order, municipal authorities and the police tended to look the other way when coloureds and Indians moved into the inner city. More significant, suggests Morris, were the events of 1982. In that year, Judge Richard Goldstone, presiding in the Govender case, ruled that it was illegal to evict tenants flouting the Group Areas Act without providing them with alternative accommodation. Black settlement had increased significantly in Hillbrow during the 1980 s as young, employed, relatively welleducated black South Africans sought to escape the massive and violent revolts taking place across South African townships. This was further exacerbated by the abolition of Influx Control in 1986. Given the terrible overcrowding in townships arising from the failure of the state to add significantly to the housing stock for blacks since the 1970s, the decision gave some security to black inner-city tenants. This was sometimes welcomed by landlords eager to lease apartments left empty by white residents. Landlords were also motivated, Morris suggests, by the prospect of extracting higher rents from still vulnerable black lessees. He found that despite media hype about the area's "decline," in this initial phase of migration, new residents had a class profile (in terms of income and education) similar to that of their (former) white neighbors. He also found that flat densities in the 1980s had only marginally increased, putting lie to the myth of a black underclass overcrowding flats in order to meet their rent obliga- 
tions. At the time of his study, he found that the urban poor and homeless were not living in blocks of flats, but rather on the streets. This was especially true of significant numbers of street children, many involved in illicit activities to survive. It was this situation that contributed to a sense of the area's decline and aggravated a sense of threat in the inner city.

By the late 1990s, however, there were visible signs of deterioration in the inner city. The public discourse at the time blamed the antisocial and sometimes depraved behavior of the new migrants. Morris does not simply dismiss these claims. He agrees that immigrants to the city at times displayed an inexplicable disregard, even purposeful malice, for their environment (333). But this was the least of it. Two other factors massively overshadowed problems of incivility: overcrowding and poor maintenance. Given that landlords were overwhelmingly white and new tenants, black, it is easy to explain what happened simply in terms of racism. This was undoubtedly a factor. What such an explanation obscures, however, is the role of landlords as property owners. In other words, it obscures larger structural factors related to the market.

By the mid-1980s, white vacancy rates were increasing and landlords, rather than lowering rentals to reflect new levels of affordability, allowed overcrowding as a way of maintaining real income. This was made possible by the massive demand for accommodation from black South Africans and their weak bargaining position as "illegals" in terms of the Group Areas Act. Morris notes that in Hillbrow, the shift in the composition of the population was not only racial but also one of class (108). Many of the new arrivals in the inner city had only modest incomes and could not afford high rentals unless they shared with friends, relatives, and occasionally with strangers. In some cases, flats that had accommodated a single person were being rented out to as many as eighteen people (100). The following incredible story was told to Morris during his research:

"Back in $1982 \mathrm{I}$ used to manage these buildings with elderly ladies. On the 27 th when they get their pension they come and pay and by the 1st the whole block is paid. So in 32 flats you'd have 32 old ladies and those old ladies will go to town twice a week, so they'll go down the lift twice a week.... They go to the toilet once a day. Where you now get these landlords-they thought they were clever-they will charge R300 to the blacks and in the meantime put eighteen people in a flat. So you've got eighteen people going to the toilet, eighteen people going up and down a lift bundreds of times a day, and shebeens. I mean this is what the problem is. We used to have one handyman servicing eight buildings. We've now got fulltime plumbers and electricians and it's costing thousands of rands a month to maintain the building." (cited in Morris 1999:100)

In some cases, white residents paying modest rentals were actively encouraged, even forced, to vacate their flats to make way for exploitable new arrivals. Overcrowding massively increased the wear and tear on build- 
ings and pushed up maintenance costs. Landlords seldom responded adequately, with the consequent decline in buildings. Why? Racism, undoubtedly, played a role: certainly the belief that blacks expected, indeed should expect, a lower quality of service. Over and above ad hominem prejudice, there were a host of structural factors. High interest rates during the $1980 \mathrm{~s}$ and early 1990 s made mortgage repayments expensive. Even if there was genuine goodwill from some landlords to maintain their buildings-and Morris notes many examples - their room to maneuver was often constrained by the costs of ownership. This was exacerbated by shifts in the property market itself. If in the past landlords held property as a capital asset, the decline of the market increased the importance of rental incomes. In other words, if the worth of a building did not come from its market value, then the worth of the building more and more depended on the ability to extract rents. Morris quotes the manager of housing policy at First National Bank as saying at the time: "I can understand the landlord to a certain extent. Because, let's say you buy a building for R3 million and the resale value of the building deteriorates all the time. So, what does he do? He just grabs whatever he can. It's a short-sighted attitude, but I think most people faced with the same sort of thing will do exactly that" (cited in Morris 1999:111).

This was aggravated by the financial situation of many landlords and the age and condition of the buildings. A lot of the buildings were owned by individual investors, as opposed to large corporations, without the capital resources to take a long-term view. Faced each month with growing mortgage and maintenance costs and without huge capital savings, they struggled from month to month. When there was goodwill, landlords struggled, not to make a profit, but to pay their bills. Landlords resorted to different and often multiple strategies to deal with the situation. As the burden of ownership increased, so landlords increasingly turned to third parties. Some resorted to middlemen instead of managing agents. The difference is significant. The agents tended to rely on legal mechanisms to enforce payment and to secure evictions in the case of nonpayment. Middlemen often used bullying and coercion. In some cases, landlords simply abandoned their buildings altogether.

In this heady cocktail of decline, social relations become more and more acrimonious. Tenants accused landlords of racist neglect. Landlords blamed residents for willfully damaging buildings. Morris writes: "There is little doubt that there were tenants in Hillbrow who viewed the landlord as the enemy who needed to be undermined at every opportunity. In the pre1990 period especially, conflict with the landlord was viewed by some residents as an extension of the anti-apartheid struggle" (134). Under conditions of often gross exploitation, poor maintenance and a general sense of grievance, tenants resisted in various forms. Sometimes they refused to pay their rents, or agreed to pay only a portion of it. There were also acts of wanton destruction. With the emergence of ActStop in the 1980s, resistance became more organized. The group, operating under the umbrella 
of the then United Democratic Front, sought to establish residents' committees to negotiate with landlords and/or their representatives. Often they organized rent boycotts or set rents themselves. What is clear, suggests Morris, is that the balance of power between affected landlords and residents shifted. Morris writes: "The blocks of flats in Hillbrow which experienced dramatic decline in the late 1980's and early 1990's were the ones where the loss of landlord control was so great that the conventional tenant-landlord obligations... had collapsed. Landlords or the managing authorities of these buildings were not able to enforce their authority" (139). Indeed, control of many inner-city buildings passed to new forms of organization. I will return to this question shortly. It frames a large part of the contemporary literature on the inner city. For the moment let us return to a crucial question.

We have seen that the effects of the decline in the property market of Hillbrow had grievous consequences for social relations in the area and on the physical environment. What caused this market collapse? Was it driven by factors peculiar to Hillbrow or to the residential market? Or was it driven by wider economic factors?

In public discourse and dinner-table conversations, the decline of the inner city is often explained in terms of racism and physical decline. The argument goes something like this: As Africans moved into the inner city, white residents and businesses, fearing the economic future of a city inhabited by blacks, fled to the northern suburbs. Vacant properties and a general crisis of confidence caused the massive devaluation of the property market. The flip side of the argument suggests that business reacted more to the insalubrious environment (noise, mess, crime) - the result of the relative lack of municipal support for the urban core during the $1980 \mathrm{~s}$ (Czegledy 2003:289). The terms of this discussion are a little like the chicken and egg question. Which came first? Soraya Goga (2003) offers a more nuanced view. He suggests that increased car usage, parking problems, and the desire to reduce the distance between work and home spurred interest in the relocation of businesses. This was accentuated by demands for types of working spaces different from those available in the central business district (CBD), including parklike settings, more modern buildings, and buildings designed for new technological needs. Counting as push factors, according to Goga, were worries about the changing racial profile of the city as well as concerns about crime. Yet, he argues, real estate investors and owners did not simply react to user demand for relocation. Nor were they responding to a shortage of supply. Incredibly, Goga notes, massive investment flowed into areas like Sandton despite the fact that demand was low and yields and rentals were falling across the entire city. Much of this investment, moreover, came from companies that owned substantial property in the CBD. "This meant," he argues, "that CBD owners... undermined their investments in the CBD and also their metropolitan real estate portfolios" (72). This is precisely the paradox that Goga sets out to 
explain. His argument is that investment decisions were not driven by socalled market rationality. They testified, rather, to the character of the financial sector: that it is dominated by oligopolies (several large and dominant companies) that operated under conditions of what he calls "false competition" (72).

In the $1980 \mathrm{~s}$ high inflation rates led to increased household investment in insurance and pension funds. These were seen as better savings vehicles than either the stock market or the banks. The assets of these institutions increased 74-fold between 1961 and 1988. In turn, these companies sought investments for their capital. International sanctions and stagnation in the manufacturing sector, however, left few possibilities. Long-term financial institutions thus switched to real estate (Goga 2003:73). Goga quotes the research manager for Old Mutual Properties as saying: "The South African market was like a pressure cooker by the end of apartheid. There was more and more money chasing less and less investments, so we pushed it into property" (74). A large proportion of this overaccumulated capital was sucked out of the CBD into places like Sandton. Pension funds and insurance companies, however, were not reacting to market demand. They were reacting to each other. This is what he calls "false competition."

The pension and insurance sector is dominated by a few large players (Old Mutual and Sanlam receive two-thirds of the total premium income) that exercise an effective oligopoly over the market. Institutions are not legally obliged to use independent assessors when valuating buildings. Instead, they do it themselves. Given, moreover, that these companies were looking for long-term investments, they were not discouraged by the inability to rent out floor space. Goga thus remarks that the values reported on the books were largely fictitious (78). Property in decentralized locations was deemed a good investment even when actual returns, in terms of rental income, were poor. This fueled the oversupply of space in decentralized locations. In contrast, the $\mathrm{CBD}$ was regarded as a devalorizing environment, in part because buildings were usually older than twenty years. Goga writes that a flawed property management system, moreover, did not see declining rent across the metropolitan area, only increasing returns from decentralized developments (79). Given that most institutions held substantial property in a CBD deemed to be devalorizing, companies like Rand Merchant Bank, Liberty Life, Ampros, and AFC Holdings "spread their risk" by investing in Sandton and Sunninghill, in Bruma Lake and in Parktown. Yet they were under pressure, not so much to generate a rental income from these investments, but to demonstrate confidence in decentralized locations. In short, occupancy rates in these developments needed to be seen as high. In many cases, institutions transferred clients from their own CBD investments to Sandton and other decentralized locations. Not only did this fuel the oversupply of office space and further weaken rental incomes across the city, but it contributed to the massive devaluation of CBD property. 


\section{Governance and Regulation}

We have discussed how the devaluation of property across the inner city had especially severe consequences for class relations in the urban core. This was as true for relations between landlords and residential tenants as it was for landlords and new commercial tenants. As struggles between these social groups intensified in the 1980s and 1990s and took on more organized forms, so buildings and neighborhoods increasingly passed to the control of other forms of authority. These were neither municipal nor business. What was the nature of these new systems of control in the inner city? This is the question that has informed a growing literature on Johannesburg. It draws extensively from comparative research in other African cities, where local government is at best one among several agencies and networks controlling the flow of things and people. It draws, too, on a growing body of work on migration in Johannesburg, considering in particular the networks of foreign, African migrants.

In "People as Infrastructure: Intersecting African Cities and a Larger Urban World," Abdou Maliq Simone (2004) situates Johannesburg in a larger African context of what he terms "ruined urbanization" $(1)^{1}$ By this he means that the "truncated process of economic modernization at work in African cities has never fully consolidated apparatuses of definition capable of enforcing specific and consistent territorial organizations of the city" (3). What is more, he argues, "State administrations and civil institutions have lacked the political and economic power to assign the diversity of activities taking place within the city (buying, selling, residing, etc.) to bounded spaces of deployment, codes of articulation, or the purview of designated actors" (3). These are difficult and opaque observations. The argument becomes clearer in an article by Maliq Simone and Graeme Gotz. In "On Belonging and Becoming in African Cities" (2003), the two authors observe that "conventional approaches to urban governance emphasized the need for individuated, clearly identified units-be they citizens, households, communities, associations, or institutions-to be held in fixed relations to each other" (123). What they mean is that government, in order to rule, is driven to impose some form of coherence and order on the areas with which it is charged. It does so by assuming that the society under its jurisdiction is composed of certain identifiable entities with which it can work or enter relations. If we return to the history of tenant-landlord relationships above, the argument becomes clearer. We saw that in order for blocks of flats in Hillbrow to remain relatively well-run, a certain form of order needed to prevail. Residents and owners needed to act in predictable and transparent ways (pay rent, maintain the building, etc.). Put differently, residents needed to become tenants in the same way that owners had to behave as landlords, with both categories implying duties and responsibilities. Things went awry precisely when this order collapsed. In the same way, Maliq Simone and Gotz suggest, a municipal authority is dri- 
ven to suppose that the society under its jurisdiction is composed of stable relations that are visible and knowable. If it is not, it needs to impose such an order. The problem is that in Africa, state administrations do not have the power to do this. Nor has the economy imposed any predictable and visible order on society.

In Johannesburg, like in other African cities, the social forms that have emerged in the absence of municipal and/or formal economic control are fragmented, flexible, and often elusive. Maliq Simone and Gotz write:

Various African actors and social ensembles are not simply striving to
reassert a sense of belonging. African identities also display a remarkable
capacity not to need fixed places. Historically, African urban actors have rev-
elled in the interstices of stability and instability, individuation and forms
of social solidarity, rural and urban, colonial zones of domination and
spaces of relative autonomy, the material and spiritual, home and non-
home. In some instances, the tentativeness of established modes of
belonging is calling forth an historical capacity to configure highly mobile
social formations that focus on elaborating multiple identities. (2003:125)

In short, the new forms of organization in the city-what Maliq Simone calls infrastructure-are characterized by their provisional and transitory form. Not only are solidarities and relationships unstable, they are sometimes held together (or torn apart) by esoteric beliefs and divine cosmologies. Municipal authority or the power of landlords has not simply been replaced by the power of other organizations. Rather, a very different kind of order has been established, based on transience and opacity. This is true, they suggest, even in the drug trade. Writing of the narcotics industry in Hillbrow, Gotz and Maliq Simone have this to say: "The modalities of operation of the drug business provincializes certain parts of the inner city, localizing it in terms of clearly marked territories and fiefdoms. Thus, most inner-city residents know which hotels, residential buildings and commercial enterprises belong to which syndicates and to which nationalities these syndicates belong" (132). If this implies the emergence of stable new syndicates and firms, Gotz and Maliq Simone warn, however, that "despite territorialisation, the definitiveness of organizations and their spaces is often more a necessary performance than something descriptive of actual operational practices. The more entrenched and expansive the drug economy becomes, the more it must proliferate ambiguous interfaces" (133). In other words, the emergence of stable organizations is more appearance than reality.

This is precisely why Johannesburg is witness to a "ruined urbanization." Movement to the city is not associated with the stabilizing of identities and the formation of durable collectives. Rather it is premised on exchanges and associations that fail to congeal, to become institutionalized or regularized. Maliq Simone suggests, therefore, that the challenge of the 
inner city is for researchers, policymakers, and urban activists to practice ways of seeing and engaging urban spaces that are characterized simultaneously by regularity and provisionality (2004:2).

In the course of reviewing municipal interventions in the Rockey Street Market and the Park Central Taxi Rank, Gotz and Maliq Simone suggest that the municipality worked well when it facilitated a process that did not require the individual parties to give up their basic identity (2003:146). Presumably by this they mean a process that lets parties come together to reach binding agreements but that respects the autonomy of each. This is not possible, however, when the "identities" in question fail ever to congeal as bodies or institutions. How can there be a binding agreement between interests when the latter are constantly dissolving and reconstituting differently? This is an inconsistency at the heart of "On Belonging and Becoming." If what characterizes new social forms in the inner city is precisely that they are provisional, how can they simultaneously be party to durable arrangements? Surely contracts and agreements require that "interests" crystallize into organizations, even when they have their own and often obscure ways of working.

Whatever criticisms we may have of such studies, their merit comes from making explicit how government is driven to make certain normative cultural assumptions about the makeup of society. In other words, they show how notions of order and contract and clarity, key to the practice of government, are premised on assumptions about the identity of individuals, households, and organizations, and the way they behave. Like postcolonial literatures that have brought to the fore how apparently universal notions of justice and equality imply particular cultural forms (European, for example), Maliq Simone and Gotz argue that governmentality does likewise, excluding or obscuring survival strategies and social networks peculiar to African cities. In this tradition, we can note some of this author's own work. In "'Functional' and 'Dysfunctional' Communities: The Making of National Citizens" (2003), I consider the development practice of the former Department of Community Development (Devcom) in the City of Cape Town. The intention was to show how development concerned not just the provision of services, but equally, attempts to organize people in particular social formations, in this case the nuclear family.

In Manenberg, the City of Cape Town was faced with a daunting and surprising dilemma. It sought to deliver services and housing in and through forums that provided for high levels of community participation. What it found was an area where residents were more and more dependent for survival on a drugs-based informal economy controlled by violent gangs. Manenberg was prone to violence. Rape and attacks on women were frequent, incest was not uncommon, teenage girls had a high pregnancy rate, and there were high levels of alcoholism and drug use. In short, according to officials, Manenberg residents were "dysfunctional." What prospect was there for democratic participation when disputes were resolved violently, 
when criminal gangs controlled most of the area, when women were under constant threat, when municipal workers feared for their lives, when development budgets were consumed by the costs of safety and security? If development was to come about democratically, something had to happen to Manenberg residents. They had to become, according to Devcom's problematic, "functional." In Devcom's practice, dysfunctionality was said to be caused by the crisis of the family in Manenberg. High levels of long-term male unemployment, accompanied by the fact of female breadwinners, meant that men struggled to realize their (patriarchal versions of) masculinity in and through "normal" activities (work, as heads of the family). This translated into high levels of pathological male behavior: alcoholism, wife battery, and so on. In turn, the disintegration of the nuclear family saw many Manenberg youths socialized not in the confines of the home and through parental direction, but on the street in and through the gangs. For Devcom it meant that the measure of development was the degree to which it contributed to rebuilding the coloured nuclear family.

Within Devcom there was an alternative approach as well. The route to functionality was to be achieved not so much through social engineering at the level of the family, but rather through social engineering at the level of the political. Residents would become functional by being forced to behave virtuously in and through participatory democratic forums. In short, the efficient and effective delivery of services depended on the orderly functioning of the development forum. And for this to happen, residents had to acquit themselves democratically, peaceably, and so on.

\section{Development and Partnership}

Let us return to the idea that inner-city society is characterized by its provisional and transitory infrastructures. We will see that there are several worrying consequences that follow from this argument.

In Uniting a Divided City (2002), Jo Beall, Owen Cranshaw, and Susan Parnell argue that the extent and complexity of urban poverty, inequality, and social exclusion in Johannesburg have been underestimated and inadequately explained by those trying to understand and intervene in the urban experience (4). This, they suggest, has made it more difficult for decision-makers to balance harsh fiscal and administrative realities with demands for social justice (3). At stake for them is the question of partnerships. With whom can government partner, or should government partner, in order to overcome poverty and inequality in Johannesburg?

They argue that the tendency to concentrate on improving the economic viability of central Johannesburg has worked against the interests of ordinary inner-city residents. This is manifest, they suggest, in the council's market construction projects and its uncompromising approach to informal traders. The council classified informal traders either as "entrepre- 
neurs"- those with capital to set up and run a business—or "survivalists"those who trade for subsistence purposes. It then privileged the former at the expense of the latter. In other words, markets were established to encourage hawkers to become entrepreneurs rather than survivalists. This taxonomy (way of distinguishing between people and things) created competition between foreign African traders and South African hawkers. Foreign-particularly West African-traders, they observe, tend to be more experienced and organized than their local equivalents. As a result, they tended to receive prime locations in markets, leaving South African traders feeling that they had been inadequately consulted and even excluded. Competition between South African and foreign traders helped fuel xenophobia and caused "pavement wars" to break out across the inner city (2002:117).

Maliq Simone and Gotz cast this clash as one between a logic of "belonging" and a logic of "becoming." By this they mean a clash between those who claim a specific, fixed territory in order to earn a living (belonging) and those who are less dependent on a space-bound identity to do business (becoming). In these terms, South African traders asserted their belonging to Yeoville as a way of countering foreign traders who were immersed in translocal and transnational networks (Gotz \& Maliq Simone 2003:124). We might wonder, however, if the heart of this conflict is less a contradiction between different approaches to "regrounding social relations" (Gotz \& Maliq Simone 2003:124) and more a question of capital and partnership. Can we be sure that South African traders are necessarily attached to specific territories (like Yeoville) in order to do business? Is the difference surely not one of capital? Local traders, unlike their foreign counterparts, often do not have access to sufficient resources to set themselves up as businesses. In privileging "entrepreneurship" over "survival," did the council not, effectively and perhaps unwittingly, favor foreign traders over South Africans? This is one of the key insights of sociology. The notion of entrepreneurs versus survivalists is not simply a general concept. In specific times and places these terms refer to particular people: speaking specific languages, belonging to particular cultures, practicing certain religions, and so on. This is why conflicts between different socioeconomic groups often take the form of religious, ethnic, and national clashes.

Why did the council choose to privilege "entrepreneurs" as opposed to "survivalists"? Did this reflect a growing ideological trend in the metropolitan council in favor of business instead of the poor?

In Johannesburg: One City, Colliding Worlds (2004), Lindsay Bremner discusses the council's preoccupation with being a "world class city." She writes, with characteristic flare:

The newly honed Joburg 2030 Vision has Johannesburg aspiring directly to "World Class City" status. According to this plan, by 2030 , international 
corporates will have been enticed out of their cushy New York, London or Tokyo offices into safe, middle-income, wide-bandwidth Johannesburg. Our economy will lie firmly in a globally competitive service sector (trade, finance and business, information and communication technology) and the city's poor will have migrated to "lower costs centres" to where the manufacturing sector will have relocated.... Johannesburg's citizens, we are told, will be living a lifestyle closer to that of a citizen of San Francisco, London or Tokyo than of the unofficial capital of a developing country. $(77-78)$

Associated with this urban vision, local economic development came less and less to mean negotiating with communities about poverty. Increasingly, it referred to global competitiveness and economic growth. Bremner attributes this shift to political struggles in the council and specifically to the ANC's tightening its political belt and forcing out members who challenged its more conservative line. More and more the public sector began acting like a private company. Johannesburg had cast off its radical, democratic ambitions to reinvent itself on neoliberal grounds. Bremner laments that what is missing from Johannesburg is a connection with ordinary people, with everyday life. Instead, quoting Xolela Mancgu, she suggests that the official language of Johannesburg is directed at investors (89). In this version, the choice to work with "investors," as opposed to poor communities, is ideologically and politically driven. It is a further sign of government's conversion to neoliberalism. Bremner's work resonates here with others who argue that the government has jettisoned the poor in favor of capitalist growth. ${ }^{2}$

There is also a more ad hominem version of this argument in her book. Less a symptom of political conversion to the right, Johannesburg's inner-city policies smack of the personalities responsible for them. Leading the inner-city regeneration drive are suit-and-tied, middle-class, middleaged white men who lack the authority or the imagination to make it succeed (Bremner 64).

Whatever the merits of the argument above-that a political/ideological shift has happened in Johannesburg that favors partnerships with investors rather than the poor-it obscures another factor as well. We can hear something of it in Bremner's interview with Rashid Seedat, director of the Corporate Planning Unit in Johannesburg. Contrasting the new emphasis on global competitiveness with former local economic development strategies, he says, "We put on our overalls and led clean-up campaigns, sat night after night in informal settlements negotiating with people around their poverty, built clinics, campaigned for Masakhane and set up art competitions at primary school to discover what children wanted the city to be" (cited in Bremner 2004:88). He concludes that these efforts were misplaced. Yet it is difficult to mistake the disappointment and impatience that such partnering evokes.

In their research on Johannesburg, Beall, Crankshaw, and Parnell 
found that "although they [the Johannesburg Development Agency] engage in widespread consultative processes and pay lip service to participatory democracy, the projects to which they give rise remain dominated by powerful interests, and the benefits rarely spread beyond the precinct" (2002:128). So the question remains: why only lip service to participatory democracy? Beall et al. hint at an answer that breaks with the standard "talk left, act right" explanations:

[The] ICO with the support of the metropolitan council has sought to upgrade failing apartment blocks and to contain dysfunctional areas, a policy supported by formal capital operating in the city, keen to limit the spatial spread of drugs trade, prostitution and the seamier side of inner city life. In combination with the introduction of individual metering and billing systems, the council uses local by-laws as a way of addressing problem buildings, such as hotels or night clubs as venues for sex workers or where drug dealers operate. Unable to deal with the people inside, the buildings are closed down for contravening health, food or fire regulations, or where there are absentee landlords and squatters take over. (117)

It is not only tiresome working with communities or poor tenants when the benefits for development are inconclusive. Rather, government often does not know with whom it should work. As in Manenburg, the inner city is home to people who, from the point of view of government, are "dysfunctional." Some are involved in illegal trades or implicated in undesirable activities. ${ }^{3}$ The sense that there are no partners for government among urban residents is exacerbated by the work of Abdou Maliq Simone. If inner-city residents are sometimes caught up in criminal activities, or if the associations they form are fleeting and unstable, then with whom can government work? Who should be government's partners in the inner city? Such studies create the impression that "community" in the inner city is dead.

This is the argument of Barbara Lipietz in "Muddling-Through': Urban Regeneration in Johannesburg's Inner City" (2004). She argues that current regeneration initiatives in Johannesburg are less the result of deliberate neoliberal policies, purposively and methodically implemented, than the result of (at times desperate) attempts to cope with highly complex and unstable situations. Although government has tried to work directly with poor communities-through shared-ownership schemes in buildings and tenant arrangements-these have proved difficult to manage. She argues that "courting the private sector for City officials then, has more to do with a desperate response to a highly intricate situation of spiralling decay, a pragmatic response to the disorderly city, to disorderly civil society" (9).

There is a danger of positing inner-city society as fundamentally provisional, fleeting, and chaotic. It can be used to legitimize forsaking working 
with the poor in favor of other partners. Formal capital has money and is, at least, organized, predictable, and involved in legal (if not virtuous) practices.

In their study of housing rights and evictions in Johannesburg, a multidisciplinary research team put together by the Centre on Housing Rights and Evictions (COHRE), found that the urban poor were not so much chaotic, criminal, and involved in provisional solidarities. ${ }^{4}$ They were usually simply poor. "To be sure," they write, "the inner city of Johannesburg is home to a large number of poorly maintained buildings .... Buildings have people living in unhealthy conditions, are structurally unsafe or have inadequate fire prevention regimes. These conditions are obviously unacceptable, and sometimes pose a danger life and health." "But," they continue, "the municipal critique of 'bad' buildings goes further than the assertion that they are unhealthy and unsafe. The municipality caricatures these buildings as 'sinkholes'; hives of criminality, which degrade the public environment and defeat the purpose of inner-city renewal" (COHRE 2004:5). "Bad buildings," according to this discourse, are not simply unsafe; they create ungovernable climates.

The COHRE team set out to investigate these claims by conducting a large number of interviews, focus groups, and surveys across ten buildings and one evicted community in the inner city of Johannesburg. ${ }^{5}$ They found that across and within the buildings they investigated there was a wide variation in tenure arrangements, physical conditions, and earning capacity of residents. Some were run-down and occupied by the working poor taking home very low but at least regular incomes. Others were more like informal settlements with people living in abject poverty. In very few of the buildings did residents have formal jobs and earn more than a R1000 per month. In all cases these buildings had become "bad" because relations between landlords and tenants or between management companies and tenants had collapsed. In many cases, units had changed hands informally several times because owners had long since abandoned their properties. Yet despite often terrible conditions, people tolerated their living environments because the inner city was perceived to be an easier place to survive without formal work than either the township or informal settlements or the rural areas.

The COHRE research offers a more salutary view on life among the urban poor than that suggested by some of the literature discussed above. To take but one example: In Park Court in Yeoville, set out for eviction because of the risk of "subsiding" (exposure to raw sewerage, inadequate fire precautions, and piles of rubbish blocking stairwells), they found a "strong sense of community" with tenants "deeply embedded in associational life in Yeoville" (9). Park Court residents were poor but neither illegals nor criminals. Indeed, they argue that most residents in "bad" buildings were more likely to be the victims of crime than criminals themselves (15). 
This is the risk of exaggerating the degree to which inner-city society is either criminal or elusive. It can serve to justify a politics of further social exclusion. In the case of inner-city buildings, it serves to legitimize partnerships with investors at the expense of facing a more fundamental and painful problem: providing those earning less than R1000 per month with safe, affordable inner-city accommodation. When we realize, following the work of Goga above, that the problem is not simply one of rebuilding the relationship between tenants and landlords, but is contingent on the structure of the property market as a whole, then the problem sometimes suggests a nonmarket solution. Most landlords do not rely on the capital appreciation of their buildings to make a profit. They are dependant for rentals to generate an income or to meet their costs. If inner-city residents tend to be either poor or very poor, then what chance is there for inner-city regeneration? What possibility is there for a process that seeks both to improve the quality of buildings and the general environment and also meets the needs of the poor?

\section{New Literatures on the City}

There is a new challenge to the way that South African academics have conceptualized the city. It has recently found expression in a special edition of the American journal Public Culture (vol. 16, no. 3, 2004). At stake are the normative conceptions underpinning certain analytical enterprises. What is at stake is the value of certain types of questions (about poverty, about democracy, about social justice) over other sorts of questions (about culture, for example).

In their introduction in Public Culture, Achille Mbembe and Sarah Nuttall write that scholarship on Africa tends to be dominated by analytical and normative strands of functionalist, neoliberal, and Marxist political economy. South African scholarship on the city, they suggest, is not very different. Much of this literature, they hold, is theoretically unsophisticated (it is instrumentalist and functionalist), though empirically rich, and addressed to larger issues of social justice, social cohesion, equity, and efficiency. What do they mean? The trouble is that these studies approach the city as a problem to be solved, seeking, in this way, to contribute to policy formation in a variety of fields. Hence most of these studies read Johannesburg as "nothing but the spatial embodiment of unequal economic relations and coercive and segregationist policies" (8-9). Mbembe and Nuttall are critical of such approaches. They ask: How do we "overturn such readings" (6) that "underplay many other aspects of city life and city forms?" (13). They want us, instead, to focus on the city as a "site of fantasy, desire and imagination" (11). "The city," they argue, "is not simply a string of infrastructures, technologies, and legal entities... It also comprises actual people, images and architectural forms, footprints and memories; the city is a place of mani- 
fold rhythms, a world of sounds, private freedoms, pleasures and sensations" (16). It is not simply workers, the poor, criminals, and illegal immigrants that live in Johannesburg. The city is home also to "civic-minded public intellectuals," to "skilled migrants," "jet setters," and a "new black elite" (22).

In and of itself, this sounds like an important corrective to a scholarship that has tended to ignore questions of culture in Johannesburg and to focus on the poor. Achille Mbembe (2004) seeks out these "manifold rhythms" and "sounds" and "freedoms" and "pleasures" in Melrose Arch and Montecasino. Both are private developments that cater to the middle classes and wealthy elites. Sarah Nuttall (2004) looks for them in the Zone, a commercial shopping center in Rosebank. Potentially, this new interest in pleasure and imagination is important. It asks us to start inquiring about the city in terms of what people make of it and desire there. How do they use public spaces, not simply as functional entities (places to work, etc.) but as places of sociability, of walking, of wandering, of shopping, of meeting? If we think in this way about the city, as a place of hospitality instead of simply as a place of surviving, working, earning a living, then we ask different questions about the city. We can think about a city in terms of democracy, for example, not simply in terms of economy and politics. We can think about it in term of values and culture: of city form. What would it mean for Johannesburg to be a place of democratic urbanity? How would people relate to one another in such a city? How would they use public spaces? What would it mean for it to be hospitable to the poor, to the marginalized, to the migrant, to the foreigner?

It is unfortunate that Mbembe and Nuttall do not take up these sorts of questions. They have a different objective. They want to find in Johannesburg a way of "defamiliarizing" the way that Africa is understood. As opposed to the Africa that always is constructed as different, as absolutely different, as failed and as incomplete in academic and public discourse, they want to emphasize the dimension of what they call the "sameness-inworldliness" of Africa (2004:2). They do this through the idea that Johannesburg is a metropolis. "We are persuaded," they write, "that in Africa, analyses of capitalist modernity have not fully apprehended the fact that it is not simply in the North that "the culture of modernity became synonymous with the culture of the metropolis" (16). In other words, they want to show that "capitalist modernity" also happens in Africa. What do they mean? Johannesburg is a metropolis, that is, a place of capitalist modernity like the North, because it too is closely tied to the money economy and individuality and capriciousness and fortuitousness. As in the North, life in Johannesburg is defined through acts of exhibition or display: consumer labels and products, highways and flashing lights, store windows and huge billboards, new architectures and all sorts of technological gadgets. By looking at the way people dress, the music they listen to, the places where they eat and go out, the way that they display themselves, it is possible to 
understand how Johannesburg, and with it Africa, is like the rest of the world.

In the name of postcolonialism there is a danger, however, of valorizing commodity exchange and deliberately failing to consider the social and economic structures that sustain it. It is a way of not treating questions of poverty and class and race because they are potentially embarrassing. They might reveal that Johannesburg is, in fact, different from Northern cities. Indeed, it is uncanny the degree to which many of these new literatures resonate with the politics of Johannesburg as a "world class city," where the measure of things is New York and London and Tokyo.

\section{Conclusion}

This paper has considered a burgeoning literature on Johannesburg from the perspective of the sorts of questions it asks about the city. We have seen, in this regard, a substantial and lively literature that is concerned with questions of poverty and equality, class and race. These studies are strongly informed by the idea that the mechanisms that produce such inequalities are key to understanding the nature of Johannesburg as a city, both in terms of how its economy works and how political institutions function, but also in terms of what sort of city Johannesburg is and can be. We have considered sociological and economic studies of the inner city that try to account for demographic shifts and for processes of social and physical degeneration. We have looked at urban anthropologies of inner-city society, considering in particular new forms of social and economic organization among inner-city residents. Related to these, we discussed debates among scholars about the prospects for governing the city, paying special attention to the consequences for such readings on partnerships. We discussed, in other words, how understandings of community or the lack thereof in Johannesburg have had important effects for governance in Johannesburg. We also discussed an emerging literature, critical of that above, which seeks to shift analysis of the city toward studies of culture and identity. In particular, they seek to concentrate academic minds on the processes of commodity exchange and bodily display.

We have seen that these literatures do not simply approach the city through different disciplinary lenses (sociology or economy or anthropology or cultural studies). They come to their studies from different normative perspectives. For some the key political question of the day is one about social and political equality in its various forms. For others it is about the degree to which Johannesburg (or Africa) is different from or the same as other places in the world.

This paper has tried to bring to the fore the political (and not simply policy) consequences of these different views.

In concluding, let us return briefly to the question of Manenberg 
raised earlier. At stake in Cape Town was the following question: How do we address poverty and service provision as a question also of ethical community? In other words, the question of poverty relief and service delivery was tied to the question of producing a democratic urban culture, a democratic society. What would be a good, pleasurable, virtuous way to live in the city? These are important questions, and it is time they were raised as real political and academic concerns. Are there forms of urban, working-class sociability that are conducive to virtuous forms of community, neighborliness, and cosmopolitanism? Are there sites of social, political, and economic life that are not those of the metropolis-a bland capitalist modernity? We do not have to concede that the logic of consumerism is the only way to think about culture. Nor do we have to believe that pleasure is the exclusive domain of the wealthy and propertied classes. Again, there are important lessons from the Cape experience. In Manenberg, a wellresourced and robust participatory forum has not simply improved service delivery in the area. There are signs that it is renewing and creating relations of ethical community. What would it mean for Johannesburg to develop a form of urban living that was not simply more affluent and more efficient, but that was also democratic, where democracy here is a question of freedom, of choice, of pleasure? These are the traditional concerns of a radical democratic politics.

\section{Acknowledgments}

I would like to thank the Johannesburg Development Agency and especially Graeme Reid for originally commissioning this paper. My thanks, too, to Ross Kriel, David Zeffert and the staff of Ashira for their extraordinary hospitality and generosity. I am grateful too to William Beinart, the Oppenheimer Trust, and St. Antony's College at the University of Oxford.

\section{References}

Beall. J., O. Crankshaw, and S. Parnell. 2002. Uniting a Divided City: Governance and Social Exclusion in Johannesburg. London: Earthscan Publications.

Bond, P. 2000. Elite Transition: From Apartheid to Neoliberalism in South Africa. London: Pluto Press.

2001. Against Global Apartheid: South Africa Meets the World Bank, IMF and International Finance. Cape Town: University of Cape Town Press.

Bremner. L. 2004. Johannesburg: One City, Colliding Worlds. Johannesburg: STE Publishers.

Chipkin, Ivor. 2003. “'Functional' and 'Dysfunctional' Communities: The Making of National Citizens." Journal of Southern African Studies 29, no. 1 (March).

COHRE. 2004. "Any Room for the Poor? Draft Report of the COHRE Fact-Finding Mission to Johannesburg." Johannesburg: Centre on Housing Rights and Evictions.

Czegledy, A. 2003. "Villas of the Highveld: A Cultural Perspective on Johannesburg 
and Its Northern Suburbs." In Emerging Johannesburg: Perspectives on the Poslapartheid City, edited by Tomlinson et al. London: Routledge.

Goga. S. 2003. "Property Investors and Decentralisation: A Case of False Competition?" In Emerging Johannesburg: Perspectives on the Postapartheid City, edited by Tomlinson et al. London: Routledge.

Gotz, G., and A. Maliq Simone. 2003. "On Belonging and Becoming in African Cities." In Emerging Johannesburg: Perspectives on the Postapartheid City, edited by Tomlinson et al., 123-47. London: Routledge.

Lipietz, B. 2004. "'Muddling-Through': Urban Regeneration in Johannesburg's Inner City." London: School of Oriental and African Studies, University of London.

Maliq Simone, Abdou. 2004. "People as Infrastructure: African Cities and a Larger Urban World."

Marais, H. 1998. South Africa: Limits to Change. The Political Economy of Transition. London: Zed Books.

Mbembe, A. 2004. "Aesthetics of Superfluity." Public Culture 16 (3).

Mbembe, A., and S. Nuttall. 2004. "Writing the World from an African Metropolis." Public Culture 16 (3).

Morris, A. 1999. Bleakness and Light: Inner-City Transition in Hillbrow. Johannesburg: Witwatersrand University Press.

Nuttall, S. 2004. "Stylizing the Self: The Y Generation in Rosebank, Johannesburg." Public Culture 16 (3).

Tomlinson, R., et al. 2003. "Introduction." In Emerging Johannesburg: Perspectives on the Postapartheid City, ix. London: Routledge.

\section{Notes}

1. Sarah Nuttall very generously made this essay available to me before publication. As a result, the page numbers here do not coincide with those in the final published version.

2. See Bond $(2000,2001)$. For a similar argument, though one that is conceptually more nuanced, see Marais (1998).

3. We might note that in Manenberg, problems of working with the "community" did not involve the council's abandoning the model of democratic development. Rather, they pursued it more aggressively by investing substantial resources (both in terms of time and money) into the development forum as a way of binding residents to democratic and "functional" behavior.

4. The Centre on Housing Rights and Evictions (COHRE) is an independent international NGO mandated to protect and promote housing rights throughout the world. COHRE has special consultative status with the Economic and Social Council of the United Nations, consultative status with the Organization of American States (OAS), observer status with the African Union (AU), and participatory status with the Council of Europe (CoE).

5. These included Nos. 60-68 Joel Street and San Jose in Berea, Park Court and Kingsfold Mansions in Yeoville, and Ginwell House and Milton Court in the Johannesburg CBD. 